Abstracta Iranicanica

Revue bibliographique pour le domaine irano-aryen

Volume 22 | 2001

Comptes rendus des publications de 1999

\title{
Turkestan, komuz kirghir et dombra Kazakh. Paris, Ocora, 1997, livret et CD.
}

\section{Rédaction}

\section{(2) OpenEdition}

10 Journals

Édition électronique

URL : http://journals.openedition.org/abstractairanica/37370

DOI : 10.4000/abstractairanica.37370

ISSN : 1961-960X

\section{Éditeur :}

CNRS (UMR 7528 Mondes iraniens et indiens), Éditions de l'IFRI

\section{Édition imprimée}

Date de publication : 15 mai 2001

ISSN : 0240-8910

\section{Référence électronique}

Rédaction, «Turkestan, komuz kirghir et dombra Kazakh. Paris, Ocora, 1997, livret et CD. », Abstracta Iranica [En ligne], Volume 22 | 2001, document 658, mis en ligne le 17 février 2010, consulté le 13 octobre 2020. URL : http://journals.openedition.org/abstractairanica/37370 ; DOI : https://doi.org/ 10.4000/abstractairanica.37370

Ce document a été généré automatiquement le 13 octobre 2020.

Tous droits réservés 


\section{Turkestan, komuz kirghir et dombra Kazakh. Paris, Ocora, 1997, livret et CD.}

Rédaction

1 Les kuu qyrghyz et les kui qazaqs sont des pièces instrumentales savamment composées par des maîtres réputés, qui sont souvent à l'origine de chaînes de transmission, selon un mode propre aux cultures nomades, où les esprits des ancêtres et des Anciens sont l'objet d'une grande vénération. Le texte évoque cet aspect important de la culture qazaque et qyrghyze, et comporte des aperçus sur la structure des pièces et sur leur signification, ainsi que des détails sur leur technique et leur esthétique.

INDEX

Thèmes : 17.1.Musique

\section{AUTEURS}

RÉDACTION

Directeur de la revue et secrétariats (Paris et Téhéran) 